\title{
Linking Process Technology and Manufacturing Performance Under the Framework of Manufacturing Strategy
}

\author{
Hongyi Sun \\ Department of Systems Engineering and Engineering Management \\ City University of Hong Kong \\ China
}

\section{Introduction}

Performance improvement is the goal of any manufacturing firms. A bunch of manufacturing practices are involved as suggested in the manufacturing strategy model. These include technologies, human resources and comprehensive programmes such as total quality management (TQM) and pull production. As a result, the linkage among various practices and performance are very complicated. Previous research in this field may have some limitations. The following part will review these limitations using TQM and AMT (Advanced Manufacturing Technology) as an example and argue the necessity of using structural equation modeling to deal with multiple variables.

First, most previous research on practice-performance linkage assumes that all practices directly contribute to the performance. Therefore, the conceptual models are mostly a onelayer model. The data analysis methods are mostly simple correlation or multiple correlation. The methodology is basically exploratory. The assumption of this research argues that practices may not all be directly correlated with performance. There may be several layers from practices to performance. Therefore, a comprehensive model based on path analysis or structural equation modeling is needed to investigate the practiceperformance relationship. To specify the path-analysis model, a conceptual model is needed. In this research the conceptual framework from manufacturing strategy will be used.

Second, in previous research, the measures of practices vary from one single question to a set of questions which are grouped into a construct. It is not so common to develop constructs in AMT-performance research yet. The definition and classification of AMT are not consistent. Beaumont et al (2002) measure AMT in terms of direct (fabrication and assembly), indirect (engineering and design) and administrative (information management). Dasa and Narasimhan (2001) divided AMT into manufacturing technologies and design technologies. However, the classification of AMT is not consistent with technical definition (Groover, 1987; Goetsch, 1990; Singh, 1996; Kotha and Swamidass, 1998). In this research, AMT will be classified according to technical definition of computer integrated manufacturing (CIM). 
In summary, practice-performance linkage has been mostly studied by simple or multiple correlation analysis in single areas such as technology or quality. In modern manufacturing companies, both practices as input and manufacturing performance as output are getting more and more complicated. Therefore, the relationship must be a complex one. This paper reports the research which aims to investigate this complex practice-performance linkage in a path-analysis model. The research is based on the manufacturing strategy framework. The idea is consistent with complex performance. Complex performance is described by Lewis and Roehrich (2009) in terms of the interaction between infrastructural complexity (e.g. buildings, enabling facilities, hardware) and transactional complexity (e.g. performance involving high degrees of embedded knowledge).

The paper is structure in five sections. In section two, literature on all types of practice and performance will be reviewed under the framework of manufacturing strategy and a set of hypotheses will be formulated. In section three, methodological issues such as data collection, operationalisation, validity and reliability tests and data analysis method will be described. In section four, the results will be presented. In section five, the results will be discussed and implications for practice and future research will be explored. In the final section, the research will be concluded; limitation and future research will be discussed.

\section{A conceptual model and hypotheses formulation}

\subsection{The conceptual framework under manufacturing strategy}

Manufacturing strategy is regarded as the manner in which the business unit deploys its manufacturing resources (Hayes and Wheelwright, 1984) and effectively uses its manufacturing strengths (Swamidass and Newell, 1987; Riis, 1992) to complement the business strategy. One of the themes in manufacturing strategy deals with various linkages or alignment among business objectives, manufacturing missions, manufacturing practices and performance. This paper aims to explore the relationship between manufacturing practices and performance. The key variables are practices and performance. The related variables include performance, structural decisions, infrastructural decisions, technology, and organization. The contents and possible relationships among the variables are illustrated in figure 1 and will be elaborated below.

\subsection{Manufacturing performance}

Under manufacturing strategy theory, manufacturing practices may not directly contribute to business performance such as market share and profitability. Their immediate contribution should be those at manufacturing levels such as cost reduction, quality improvement and shortening throughput time. Therefore, in manufacturing strategy research, business performance and manufacturing performance are distinguished (Tunalv 1991, McDermott and Stock, 1999, Sun and Cui 2002, Beaumont et al, 2002). These manufacturing performance dimensions, if being well aligned with business competitive objectives, will contribute to the achievement of business performance (Dasa and Narasimhan, 2001, Sun and Cui 2002). Therefore, there should be a corresponding relationship between manufacturing performance, manufacturing missions and business objectives. So in this research on practice-performance linkage, the performances refer to manufacturing performance. In manufacturing strategy research, manufacturing 


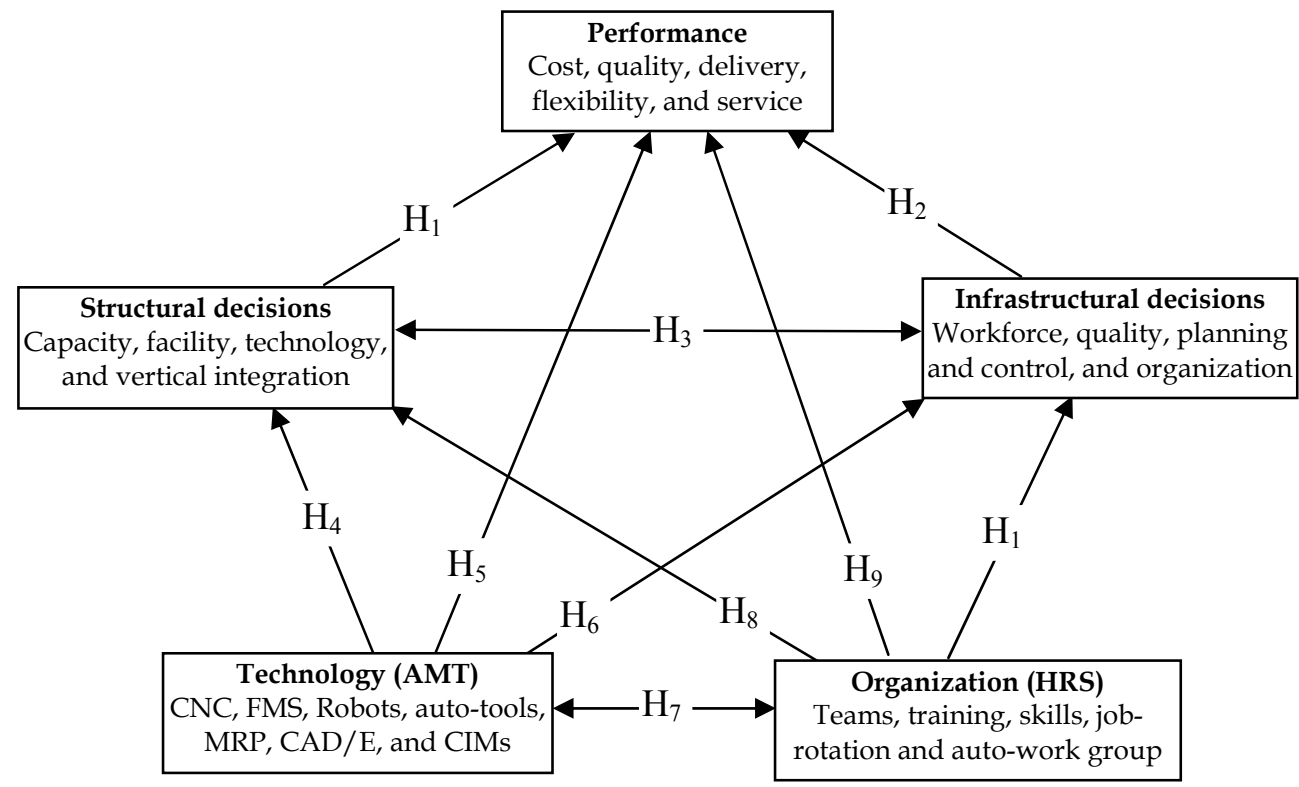

Fig. 1. A conceptual model for studying practice-performance linkage

performance should be corresponding to manufacturing missions/tasks which cover cost, quality, delivery, flexibility and service (Skinner 1969, Wheelwright 1984, Kim and Arnold 1996 etc.). The service often refers to customer satisfaction. Based on the alignment and corresponding theory, manufacturing performance can also be divided on into these five categories.

\subsection{Action programmes based on structural and infrastructural decisions}

Manufacturing action programs are often regarded as sets of decisions, that derive from the experience of a number of leading companies and that have proved to be successful (Schonberger, 1982; 1986; Hanson and Voss, 1993, Hanson et al., 1994). They are the resources or functions that must be performed by manufacturing (Schroeder et al., 1986). Because of the diversity of manufacturing decisions that must be made over time, Hayes and Wheelwright (1984) developed an organizing framework that groups them into two major categories, structural and infrastructural decisions. There is an essential agreement on this structure-infrastructure dichotomy in the literature (e.g., Leong et al., 1990; Hill 1995, Tseng et al, 1999, Ng and Hung 2001). Structural decision category addresses the "bricks and mortar" decisions of capital spending. Examples of structural decisions include decisions on capacity, facility, the investment in technology, and vertical integration (Hayes and Wheelwright, 1984). Infrastructural decision category addresses more "tactical" issues, which affect the people and systems that make manufacturing work (Leong et al., 1990). The infrastructural decisions may include decisions on workforce, quality, production planning and organization. 
Corresponding to the above two decision areas, there are two types of action programmes. Those programmes supporting structural decisions such as increasing equipment and capacity are named as structural programmes. The programmes to support infrastructural decisions and choices are named as infrastructural programmes. Regarding contribution to performance, Hayes et al. (1988) suggested that infrastructure decisions were equally important as structure decisions. Performance improvement has been found positively correlated with infrastructural programs such as quality management programs, pull production systems, total productive maintenance (Cua, McKone and Schroeder, 2001), and supply chain management. Structural and infrastructural decisions are the two sides of the same manufacturing process. So they must be related to each other. Hayes et al. (1988) suggested that the distinction between structure and infrastructure was analogous to the distinction between computer hardware and software. The fixed, long-term and often unrecoverable investments of the firm in durable or facilities are analogous to computer hardware, while those that are more controllable by management are analogous to software. Based the contents and analysis of the two types of programmes, the following hypotheses are formulated.

$\mathrm{H}_{1}$ : Structural programs directly contribute to Performance.

$\mathrm{H}_{2}$ : Infrastructural programs directly contribute to Performance.

$\mathrm{H}_{3}$ : Infrastructural programs are positively related to Structural programs.

\subsection{Technology}

Under manufacturing strategy framework, technology is part of structural decisions. However, since technology has changed dramatically in the past decades years and it has very different features compared with other items such as capacity and facility etc, technology is treated separately and refers to Advanced Manufacturing Technologies (AMT).

AMT refers to those computer-aided technologies in information management, design, engineering and fabrication processes such as Computer Aided Manufacturing (CAM), Computer Aided Design (CAD) and Computer Aided Process Planning (CAPP). AMTs are the main technical components of Computer Integrated Manufacturing (CIM) systems. It is more than a group of advanced and automated technologies (Haywood, 1990). The main feature of CIM is the total integration of all manufacturing functions, including design, engineering, planning, control, fabrication, and assembly etc. through the use of computers. According to the CIM wheel model of the Society of Manufacturing Engineer (SME), there are one business and four technical components of a CIM system (Goetsch 1990). The four technical components are planning and controlling, information resources management, product and process definition, and factory automation. The four components and relevant AMTs involved have been described in details in literature (Groover, 1987; Goetsch, 1990; Singh, 1996; Kotha and Swamidass, 1998). The contents of the four components as well as their relationship with other variables will be analyzed below.

The factory automation component contains will directly influence the structural decision on the manufacturing process, especially the level of automation, new equipment implementation, capacity incensement and facility investment (Goetsch 1990, Bessant and Haywood 1988). In fact, the structural decision is called process choices in Hill's model (Hill 
1995). Regarding the relationship between processes and AMT selection, there have been many similar models reported (Fix-Sterz et al 1987, p.11, Greenwood 1988, Lindberg 1990 p.12, Noori 1990, Ayres 1991, Parthasarthy \& Sethi 1992). In general, for small batch and large variety job shop processes, standalone NC and MC will be suggested. For medium batch and variety, FMS is recommended. For large volume and few varieties, dedicated and automated lines are suggested. All these suggest that different processes may use different type of AMTs. In either case, the changes in process will require the changes in the technological dimensions. In other words, AMT is needed to support the implementation of structural programs for the purpose of updating manufacturing processes. The above reference leads to the fourth hypothesis.

$\mathrm{H}_{4}$ : The implementation of structural programs will be positively correlated with the utilization of manufacturing technologies.

The planning and controlling component includes such elements as planning/scheduling and controlling of facilities, materials, tools and shop floor activities. Hardware and software are available to automate each of the elements. Material Requirement Planning (MRP), as well as Manufacturing Resources Planning (MRP II), is an important concept with a direct relationship to CIM. Information resources management is the nucleus of CIM. Information, updated continually and shared instantaneously, is what CIM is all about. One of the major goals of this nucleus is to overcome the barriers that prevent the complete sharing of information among all other CIM components. The AMTs used for this purpose include Shared Databases (Shared DB), Wide Area Network (WAN), and Local Area Network (LAN). Planning and control is one of the key issues in infrastructural decision. However, it needs the support of technologies such as MRP and IT system. Re-engineering program is especially based on IT system implementation. The implementation of IT systems also needs the support of the relevant infrastructural changes. The above analysis leads to $\mathrm{H}_{5}$.

$\mathrm{H}_{5}$ : The utilization of AMT is positively correlated with the implementation of infrastructural programs.

The need to achieve cost efficiency, quality, and flexibility is necessary, and has imposed a major challenge to the manufacturing industry in the nineties and beyond. AMT has been widely regarded as a new and valuable weapon to rise to the challenge proposed by the new market situation to manufacturing industries (Hunt, 1987; Noori, 1990). Therefore, AMT is widely regarded as the new weapon to improve manufacturing performance. This leads to the following hypothesis.

$\mathrm{H}_{6}$ : There is a positive relationship between technology utilization and manufacturing performance.

\subsection{Organisational dimension}

Workforce and organisation are part of the infrastructural decisions. However, the issue is different to other items such as quality, planning and control. Additionally, HRS and organisational issues have been studied intensively from AMT perspective. So the organisational issue is separated in the research. Since the scope of study is in manufacturing function, the organisation refers to work organisation on the shop floor. 
Plenty of previous research was found on the changes in human resources in association with single AMTs. Lee and Leonard (1990) discovered that the Automated Guided Vehicle $(\mathrm{AGV})$ in a small batch-manufacturing environment altered the nature of human work. Saraph and Sebastian (1992) reviewed many previous studies and concluded that the failure of AMT is mainly due to the implicit or explicit neglect of critical human resource factors. Gerwin and Kolandy (1992, p.215) said that AMT invites a wide range of changes in human resources management and practices. They further suggested that human resources development should be integrated with the design of new technologies in the manufacturing environment. Samson, Sohal and Ramsay (1993) argue that human resources issues such as commitment, involvement, the acceptance of changes, culture, work and skills should be considered for the successful implementation of AMT. According to these previous studies, the human resources suitable for AMT are characterised by lower division of labour, frequent job rotation, stable employment, active employees' participation, loose first-line supervision, more training, team-based work organisation, group-based incentive system (Sun 2001). Based on the requirement of the development in HRS and organisational dimension for AMT implement, the following hypotheses can be formulated.

$\mathrm{H}_{7}$ : The utilization of AMT is positively correlated with the adoption of new form of work organization.

The most influential research on organizational structure and technology was made by Woodward (1965) at Imperial College in England. The very original research was conducted through a survey of 203 British manufacturing firms (p.8). Woodward's research was carried out at the level of the work organization in the production department. The samples are purely industrial companies. Woodward found that type of production, i.e., the structural decision area, was related to a specific type of organizational structure. The found that production process was the most important factor deciding the organizational structure. The number of levels in the management hierarchy, the span of control of first-line supervisors, and the ratio of managers and supervisors to other personnel were all affected by the type of the employed production technology. Besides, the success or effectiveness of the organizations was related to the "fit" between processes and organizational structure. The successful firms of each type were those that had the appropriate structured technical systems. The theory leads to hypothesis H9.

$\mathrm{H}_{8}$ : The adoption of new work organization is positively correlated to the implementation of structural action programs.

HRS and organization is part if infrastructural decision area, there it is of course related to the infrastructural decisions and relevant action programmes to support the decision. For example, teams work, employee involvement and suggestions have been proved to be a necessary part of quality management program. Employee involvement in terms of suggestions and participation are associated with quality management activities such as quality circles and communication. Research has shown that job enrichment and task characteristics such as skill variety and autonomy are directly associated with higher work quality and employee satisfaction (Kopelman, 1986). Self-managing work teams typically produce positive results in terms of quality and costs (Beekun, 1989; Sundstrom, 1990). Teams are also proved to be useful for new product development (Sobek II et al, 1998). Therefore, it is natural to formulate hypothesis $\mathrm{H}_{9}$ and $\mathrm{H}_{10}$. 
$\mathrm{H}_{9}$ : The autonomous working organization is positively correlated with performance.

$\mathrm{H}_{10}$ : The adoption of autonomous working organization is positively correlated with the implementation of infrastructural programmers.

The relevant variables and would-be relationships are illustrated in the conceptual model as shown in figure 1 . The ten hypotheses will be tested in several models.

\section{Empirical data}

\subsection{Questionnaire and data collection}

The data for this research are from the International Manufacturing Strategy Survey (IMSS). The project was initiated by London Business School and Charlmes University of Technology in 1992. IMSS is an international research network consisting of 20 countries and 600 companies around the world, including developed countries, i.e. USA, Japan, British, Germany, and developing countries, i.e. China, Argentina, Mexico. The participant companies are in the metal products, machinery and equipment industry, i.e. the international Standard Industry Classification (ISIC) 38. For details regarding IMSS project, please refer to the book by Lindberg et al., 1998.

The research reported in this paper is based on the data from the third round of IMSS survey. Data collection methods varied from country to country. In some countries, sample selection was at the coordinators' convenience, and others used random sampling. Phone contact was followed in most of the participating countries, except for the Netherlands. The questionnaires were forwarded to participating companies via mailing, fax or on-site interview. In those countries where English is not used, the questionnaire was translated into local native languages. Participating countries sent their data to the coordinator who forwarded the final database to all participants. When this research is conducted, 282 sets of data are available.

IMSS questionnaire covers four aspects of manufacturing practices and strategies. In this research those questions that are related to practice and performance are selected. In the practice part, there are three sections, namely, technology, organization and improvement programs. The section on organization contains questions on suggestions, training, skills, teams, and job rotations. The performance section contains questions related to quality, flexibility, delivery, cost and customer satisfaction. These questions are listed in the Appendix.

\subsection{Method for validity and reliability tests}

Validity and reliability tests cover content validity, construct validity and reliability. Content validity refers to whether the items in a scale represent the contents of a theoretical construct. The content validity is based on literature review, research experiences, and case studies. The contents of technology, organization, improvement programmes and performance have all been reviewed and discussed in literature review section.

Reliability refers to the internal consistent of the items within a scale that aims to measure a theoretical construct. The most commonly used test method is internal consistency (Saraph, Benson, and Schoeder, 1989; Flynn, Schroeder and Sakakibala, 1994; Nunnally, 1978). It is 
estimated by using Cronbach's alpha. Peterson's (1994) summary of Cronbach coefficient shows that a value above 0.7 was thought to be sufficient in most of the situations. However, in the early stage of a research where the construct had not been well tested in previous studies, Nunnally (1967) recommended a level above 0.5 be acceptable.

Construct validity refers to whether a scale is an appropriate operational definition of an abstract variable or a construct (Nunnally 1978). It is established through the use of principal factor analysis. Factor analysis (de Vaus 1993) groups variables (i.e., single questions) into factors based on their common correlation. Those variables that are correlated with each other will be grouped together. Such a group of variables is called a factor. The grouping is based on the rotated loading coefficients. The threshold of the loading coefficients is related to the size of the sample. For example, Flynn, Schroeder and Sakakibala (1994) claim that for a sample of 100, the loading of 0.19 and 0.26 indicate significance at the 0.05 and 0.01 levels, respectively. This is based on the seminal work by Cohen (1988), who suggested that in 'soft' behavioral and management research, an effect size of 0.3 is often encountered (p.95). Based on Cohen's argument, de Vaus (1993) suggested a rule of thumb as follows: if its rotated loading coefficient is more than 0.30 , then a variable will be included in the corresponding factor; if the loading coefficients for all the factors are more than 0.3 , then the variable will be grouped according to the largest coefficient and conceptual analysis. As the sample size of this study is 250 (180 plus 71), with a 95\% confidence level and an effect size of 0.3, the statistical power of this sample is larger than 0.95 (Cohen, 1988, p.102), which is high enough to identify inherent statistical relationships.

\subsection{Construct measurement}

All the questions used in this research are coded and corresponding to the questionnaire in the appendix.

\subsubsection{Manufacturing performance and the latent variable}

Manufacturing performance is directly measured by asking the respondents to indicate the amount of change of the performance dimensions over the past three years, with $1=$ strongly deteriorated and $5=$ strongly improved. According to the classification of manufacturing mission and performance under manufacturing strategy, five constructs/dimensions are formulated as shown in table 1. All the constructs passed validity and reliability tests. Additionally, a second level factor analysis of the five performance dimensions produces a valid and reliable performance scale. This means that a latent variable of performance exists.

\subsubsection{Technology constructs and the latent variables}

Based on the classification in literature, AMT is divided onto four constructs, namely, fabrication (NC, MC and FMS) assembly, design (CAD/E), information technology (IT) and integrated manufacturing with automated materials transportation and inspection. Confirmative factor analysis revealed that the FMS and NC, MC are separated into two factors which are named standalone automation and FMS, respectively. Other items passed the factor analysis. Finally five AMT constructs are identified. Their validity and reliability tests are list in table 2. Additionally, a second level factor analysis of the five technological 
dimensions produces a valid and reliable technology scale. This implies that there exist a latent variable of technology.

\begin{tabular}{|c|c|c|c|c|c|c|c|}
\hline Code & Factors and items & 1 & 2 & 3 & 4 & 5 & Performance \\
\hline & 1. Quality: & & & & & & 0.64 \\
\hline D21 & Manufacturing conformance & 0.74 & & & & & \\
\hline \multirow[t]{2}{*}{ D22 } & Product quality and reliability & 0.72 & & & & & \\
\hline & 2.Flexibility: & & & & & & 0.39 \\
\hline D24 & Volume flexibility & & 0.88 & & & & \\
\hline \multirow[t]{2}{*}{ D25 } & Mix flexibility & & 0.63 & & & & \\
\hline & 3. Delivery: & & & & & & 0.78 \\
\hline D28 & Delivery speed & & & 0.73 & & & \\
\hline \multirow[t]{2}{*}{ D29 } & Delivery reliability & & & 0.88 & & & \\
\hline & 4. Cost: & & & & & & 0.55 \\
\hline D213 & Labor productivity & & & & 0.67 & & \\
\hline D214 & Inventory turnover & & & & 0.52 & & \\
\hline D215 & Capacity utilization & & & & 0.62 & & \\
\hline \multirow[t]{5}{*}{ D27 } & 5. Service (customer satisfaction): & & & & & / & 0.69 \\
\hline & $\begin{array}{l}\text { Extraction Sums of Squared } \\
\text { Loadings }\end{array}$ & & & & & & \\
\hline & Total & 1.73 & 1.94 & 2.67 & 1.89 & / & 1.9 \\
\hline & $\%$ of Variance & 38.64 & 54.23 & 43.46 & 39.45 & / & 40 \\
\hline & (Cronbach's a) & 0.70 & 0.77 & 0.71 & 0.63 & / & 0.60 \\
\hline
\end{tabular}

Table 1. Manufacturing performance constructs

\begin{tabular}{|c|c|c|c|c|c|c|}
\hline & Factors and items & 1 & 2 & 3 & 4 & 5 \\
\hline & 1. Integrated manufacturing: & & & & & \\
\hline BT15 & Robots & .712 & & & & \\
\hline BT16 & Automated guided vehicles (AGVs) & .602 & & & & \\
\hline BT17 & Automated storage-retrieval systems (AS/RS) & .721 & & & & \\
\hline BT19 & Computer-aided in inspecting/testing/ tracking & .666 & & & & \\
\hline & 2. CAD/E: & & & & & \\
\hline BT110 & CAD; CAE & & .817 & & & \\
\hline BT111 & CAD-CAE-CAM-CAPP & & .807 & & & \\
\hline BT112 & Eng'g DB, Product Data Management systems & & .654 & & & \\
\hline & 3. IT and MRP: & & & & & \\
\hline BT23 & Purchasing and supply management & & & .884 & & \\
\hline BT21 & Material management & & & .867 & & \\
\hline BT22 & Production planning and control & & & .786 & & \\
\hline BT24 & Sales and distribution management & & & .760 & & \\
\hline BT25 & Accounting and finance & & & .730 & & \\
\hline BT113 & $\begin{array}{l}\text { LAN-WAN/ Intranet / Shared } \\
\text { databases/Internet }\end{array}$ & & & .551 & & \\
\hline & 4. Standalone automation: & & & & & \\
\hline BT13 & CNC-DNC & & & & 0.80 & \\
\hline BT12 & Machining centers & & & & 0.77 & \\
\hline
\end{tabular}




\begin{tabular}{|c|c|c|c|c|c|c|}
\hline & Factors and items & 1 & 2 & 3 & 4 & 5 \\
\hline BT14 & $\begin{array}{l}\text { Automated tool change - parts } \\
\text { loading/unloading }\end{array}$ & & & \multicolumn{3}{|c|}{0.75} \\
\hline BT11 & Stand-alone/NC machines & & & \multicolumn{3}{|c|}{0.66} \\
\hline & 5. FMS: & & & & & 0.63 \\
\hline & Extraction Sums of Squared Loadings & & & & & \\
\hline & Total & 1.83 & 1.75 & 3.66 & 2.23 & / \\
\hline & $\%$ of Variance & 45.79 & 58.25 & 59.43 & 55.76 & / \\
\hline & $\%$ of Variance & 45.79 & 58.25 & 59.43 & 55.76 & / \\
\hline & (Cronbach's a) & 0.60 & 0.64 & 0.86 & 0.74 & / \\
\hline
\end{tabular}

Table 2. Factor analysis of technologies by CFA

\subsubsection{Organsiation construct and a representative partial model}

The organization part contains ten questions. Some of them were deleted since they are not relevant. Corresponding to literature review on HRS development, questions on training, skills, working in teams and job rotation are selected. Since the constructs for HRS development as discussed in the paper are not as common as AMT constructs, explorative factor analysis is used to explore all the items. It is found that the two questions related to training do not significantly related to other items. Scanning the data revealed that the data on training may have something wrong. Maybe due to different training systems, there are quite many data that are not explainable at all. For example, annual training hours are more than 10,000 hours. So questions on training are neglected. A question on labour union cooperation is also deleted since it is not a common question for all participating countries. The rest questions are analyzed and produce 3 factors which are named, working in teams, autonomous working group and suggestions, and skills and job rotation. The validity and reliability tests are shown in table 3. The construct "auto work org. \& suggestions" does not pass the reliability test. Its Cronbach alphas is only 0.39 , less than the minimum threshold of

\begin{tabular}{clccc}
\hline Code & & F1 & F2 & F3 \\
\hline & & Team & $\begin{array}{c}\text { Skills \& } \\
\text { rotation }\end{array}$ & $\begin{array}{c}\text { Auto work org. } \\
\text { \& suggestions }\end{array}$ \\
B06a & Team in fabrication & $\mathbf{0 . 9 0}$ & 0.15 & 0.06 \\
BO6b & Team in assembly & $\mathbf{0 . 9 0}$ & -0.01 & 0.12 \\
BO9 & Multiple skills & 0.03 & $\mathbf{0 . 8 6}$ & 0.12 \\
BO10 & Job rotation & 0.10 & $\mathbf{0 . 8 6}$ & -0.01 \\
BO5 & Suggestions & -0.06 & 0.00 & $\mathbf{0 . 8 7}$ \\
C512a & Auto work org. & 0.30 & 0.13 & $\mathbf{0 . 6 7}$ \\
& Rotation Sums of Squared Loadings: & & \\
\hline & Total & 1.72 & 1.51 & 1.24 \\
& \% of Variance & 28.59 & 25.10 & 20.60 \\
& Cumulative \% & 28.59 & 53.69 & 74.30 \\
& Cronbach's a & 0.80 & 0.67 & $0.39<0.5$ \\
\hline
\end{tabular}

Note: ** significant at the level of $\mathrm{p}=0.01$, * significant at the level of $\mathrm{p}=0.05$

Table 3. Factor analysis of human resources items by EFC 
0.05. The construct is not accepted. Instead, the two items "auto work org." and "suggestions" are treated as separate variables. So there are four variables in transitional dimension, namely, autonomous working organization, suggestions, working in team and skills and rotation.

The second level factor analysis of the four variables does not produce a valid and reliable scale. Therefore these four factors cannot be treated as a latent variable in data analysis. Based on the correlation analysis, it is found that "autonomous working organization" is correlated with all other three variables and no other correlation relationships exist. So this variable will be used as a representative variable of organizational dimension while other three are linked to the representative one. In fact, the measure of autonomous working organization is a quite representative since it covers knowledge of employees, delegation, training, improvement and autonomous teams. Details will be shown it the specified models in figure 2, 3, and 4 .

\subsubsection{Structural and infrastructural programmes}

The programmes used in this research refer to a major project aimed at producing considerable changes in the company's management practice and organization. There are fourteen improvement action programs listed in the questionnaire. These programmes cover many aspects of manufacturing improvement. However, based on manufacturing strategy framework, improvement activities can be divided into structural and infrastructural areas. Based on this concept, the programmes are divided into two groups, namely structural and infrastructural programmes as shown in table 4 . These two groups of programmes both pass the validity and reliability tests as shown in table 4 . This indicates that companies do no implement action programme individually, rather in a coherent and systematic way. The validity and reliability tests imply that there exist a latent variable of structural programs and a latent variable of infrastructural programs.

\begin{tabular}{clcc}
\hline Code & & Component & Component \\
\hline & Structural programmes: & & \\
C53A & Process automation & .767 & \\
C51A & Updating process equipment & .763 & \\
C511A & Equipment productivity & .667 & \\
C58A & Process focus & .634 & \\
C52A & Expanding manufacturing capacity & .528 & \\
\hline & Infrastructural programmes: & & .717 \\
C59A & Pull production & & .713 \\
C513A & New product development & & .687 \\
C510A & Quality improvement & & .623 \\
C56A & Restructuring supply strategy & & .582 \\
C57A & Outsourcing & & .490 \\
C514A & Environmental compatibility & & \\
& Extraction Sums of Squared Loadings: & 2.46 \\
& Total & 2.296 & 41.06 \\
& \% of Variance & 45.928 & 41.06 \\
& Cumulative \% & 45.928 & 0.77 \\
\hline
\end{tabular}

Table 4. Factor analysis of action programmes by CFA 


\subsection{Structural Equation Modeling (SEM) and model fitness test}

In this study, structural equation modeling (SEM) is used to test the hypothesis as well as the fitness of the whole model. SEM is a method that can be used to establish relationships among multiple variables. It has several advantages over simple correlation, such as considering the collinearity effect. It can also include any possible relationships among a set of variables. SEM is applied in the following procedures.

An initial model is specified and assessed by examining the whole model fit and individual parameter significance. Multiple criteria will be used to evaluate the whole model fitness (Hu and Bentler, 1999; Kaplan, 2000; Byrne, 2001), goodness of Fit Index (GFI) (Jöreskog \& Sörbom, 1984), comparative fit index (CFI) (Bentler, 1990) and root mean square error of approximation (RMSEA) (Hu and Bentler, 1998; MacCallum and James, 2000). Rule of thumb recommended by scholars regarding the fit indexes is used to evaluate the model fit. Generally, GFI and CFI value above 0.9 are regarded as a good fit; RMSEA value less than 0.05 indicates good fit and value between 0.05-0.08 (Browne and Cudeck, 1993) represents reasonable fit. For normed Chi Square, Carmines and McIver (1981) recommended the value be below 3, but a value up to 5 also represents a reasonable fit (Wheaton et al., 1977; Marsh and Hocevar, 1985). If the model doesn't fit well, it should be re-specified. Those items whose path loading coefficients are insignificant $(a>0.05)$ should be deleted for further test. In case all the measure coefficients are significant $(a<=0.05)$, the item with smallest coefficient is deleted. The process should be one by one gradually. The process ends when the whole model satisfies all the fitness criteria and all individual measurement coefficients are significant. The evaluation criteria and standards are summarized below:

- Coefficients for all paths are significant at 0.05 level

- $\quad \chi^{2} / \mathrm{df}:<3$ good fit, 3- 5 reasonable fit

- $\quad$ GFI and/or CFI: 0.9-0.95 good fit, > 0.95 superior fit

- $\quad$ RMSEA: $<0.05$ good fit, $0.05-0.08$ reasonable

\section{Results}

The data analysis includes the test of four models. The first model (model-1) is based the conventional simple correlation. The second model (model-2) is based on multiple correlation with performance as dependent variable and four practices as independent variable. The third model (model-3) is based on the conceptual model in figure 2, i.e., all the hypotheses paths being included. The last model (model-4) will be the model deleting the no-significant paths gradually, if any. The testing results of the four models are summarized in table 5 and presented in details below.

\subsection{Model 1 based on simple correlation}

In model-1, each pair of the five variables are linked separately and simple bivariate correlation is calculated. The result is shown in table 5, the column of model-1. The result shows that all the correlation coefficients are significant. Based on the results from model-1, all the hypotheses should be accepted. 


\begin{tabular}{|c|c|c|c|c|c|c|c|c|c|c|}
\hline \multirow{2}{*}{\multicolumn{3}{|c|}{ Hypotheses and paths }} & \multirow{2}{*}{\multicolumn{2}{|c|}{$\begin{array}{c}\text { Model-1 } \\
\text { Simple } \\
\text { correlation }\end{array}$}} & \multirow{2}{*}{\multicolumn{2}{|c|}{$\begin{array}{c}\text { Model-2 } \\
\text { Multiple } \\
\text { correlation }\end{array}$}} & \multirow{2}{*}{\multicolumn{2}{|c|}{$\begin{array}{c}\text { Model-3 } \\
\text { SEM } \\
\text { (Initial) }\end{array}$}} & \multirow{2}{*}{\multicolumn{2}{|c|}{$\begin{array}{c}\text { Model-4 } \\
\text { SEM } \\
(\text { Final })\end{array}$}} \\
\hline & & & & & & & & & & \\
\hline $\mathrm{H}_{1}$ & $\begin{array}{l}\text { Structural } \\
\text { programs }\end{array}$ & $\rightarrow$ Performance & 0.00 & $\checkmark$ & 0.01 & $\checkmark$ & 0.44 & $x$ & 0.01 & $\checkmark$ \\
\hline & $\begin{array}{l}\text { Infrastructur } \\
\text { al programs }\end{array}$ & $\rightarrow$ Performance & 0.00 & $\checkmark$ & 0.01 & $\checkmark$ & 0.92 & $x$ & / & \\
\hline & $\begin{array}{l}\text { Infrastructur } \\
\text { al programs }\end{array}$ & $\rightarrow \begin{array}{r}\text { Structural } \\
\text { programs }\end{array}$ & 0.00 & $\checkmark$ & / & & 0.00 & $\checkmark$ & 0.00 & $\checkmark$ \\
\hline $\mathrm{H}_{4}$ & Technology & $\rightarrow \begin{array}{l}\text { Structural } \\
\text { programs }\end{array}$ & 0.00 & $\checkmark$ & / & & 0.04 & $\checkmark$ & 0.00 & $\checkmark$ \\
\hline $\mathrm{H}_{5}$ & Technology & $\rightarrow \begin{array}{l}\text { Infrastructural } \\
\text { programs }\end{array}$ & 0.00 & $\checkmark$ & / & & 0.00 & $\checkmark$ & 0.00 & $\checkmark$ \\
\hline & $\begin{array}{l}\text { Technology } \\
\text { Auto work }\end{array}$ & $\rightarrow$ Performance & 0.00 & $\checkmark$ & 0.35 & $x$ & 0.64 & $x$ & / & \\
\hline $\mathrm{H}_{7}$ & org. & [] Technology & 0.00 & $\checkmark$ & / & & 0.00 & $\checkmark$ & 0.00 & $\checkmark$ \\
\hline & $\begin{array}{l}\text { Auto work } \\
\text { org. }\end{array}$ & $\rightarrow \begin{array}{r}\text { Structural } \\
\text { programs }\end{array}$ & 0.00 & $\checkmark$ & / & & 0.89 & $x$ & / & \\
\hline $\mathrm{H}_{9}$ & $\begin{array}{l}\text { Auto work } \\
\text { org. }\end{array}$ & $\rightarrow$ Performance & 0.00 & $\checkmark$ & 0.71 & $x$ & 0.28 & $x$ & / & \\
\hline & $\begin{array}{l}\text { Auto work } \\
\text { org. }\end{array}$ & $\rightarrow \begin{array}{l}\text { Infrastructural } \\
\text { programs }\end{array}$ & 0.00 & $\checkmark$ & / & & 0.00 & $\checkmark$ & 0.00 & $\checkmark$ \\
\hline \multicolumn{3}{|c|}{ SEM Model fitness indexes } & \multicolumn{2}{|c|}{$\mathrm{n} / \mathrm{a}$} & \multicolumn{2}{|c|}{$\begin{array}{c}\mathrm{X}^{2}=858 \\
\mathrm{X}^{2} / \mathrm{df}=3.15 \\
\mathrm{CFI}=0.95 \\
\text { RMSEA }=0.088\end{array}$} & \multicolumn{2}{|c|}{$\begin{array}{c}\mathrm{X}^{2}=516 \\
\mathrm{X}^{2} / \mathrm{df}=1.94 \\
\mathrm{CFI}=0.98 \\
\text { RMSEA }=0.06\end{array}$} & \multicolumn{2}{|c|}{$\begin{array}{c}\mathrm{X}^{2}=518 \\
\mathrm{X}^{2} / \mathrm{df}=1.92 \\
\text { CFI }=0.98 \\
\text { RMSEA }=0.057\end{array}$} \\
\hline \multicolumn{3}{|c|}{$\begin{array}{l}\text { Model fitness test } \\
\text { (Figure) }\end{array}$} & \multicolumn{2}{|c|}{$\begin{array}{l}\mathrm{n} / \mathrm{a} \\
\mathrm{n} / \mathrm{a}\end{array}$} & \multicolumn{2}{|c|}{$\begin{array}{c}\text { Not } \\
\text { (Cf., Fig.2) }\end{array}$} & \multicolumn{2}{|c|}{$\begin{array}{c}\text { Not } \\
\text { (Cf., Fig.3) }\end{array}$} & \multicolumn{2}{|c|}{$\begin{array}{c}\text { Yes } \\
\text { (Cf., Fig.4) }\end{array}$} \\
\hline
\end{tabular}

Note: $\checkmark$ : significant with $p<0.05, x$ : not significant with $p>0.05$, /: the path was not specified or deleted due to insignificance

Table 5. The path significance (p) and model fitness tests of the four models

\subsection{Model 2 based on multiple correlation}

However, simple correlation does to take collinearity into consideration. This is proved by the test of model-2, which is based on multiple correlation. Model-2 is specified with performance as dependent variable and the four practice variables as independent simultaneously. The SEM model fitness test shows that only two paths are significant while two others are not significant as shown in table 5, the column of model-2. Different results can be observed in the two models. According to the SEM principle, as long as there is a non-significant path, the whole model does not fit well and no conclusion should be drawn. The reason is that the interrelations among the four practice variables have not been considered yet. This interrelationship may influence the relationship among practice and performance, as will be illustrated in the model- 3 and 4 . 


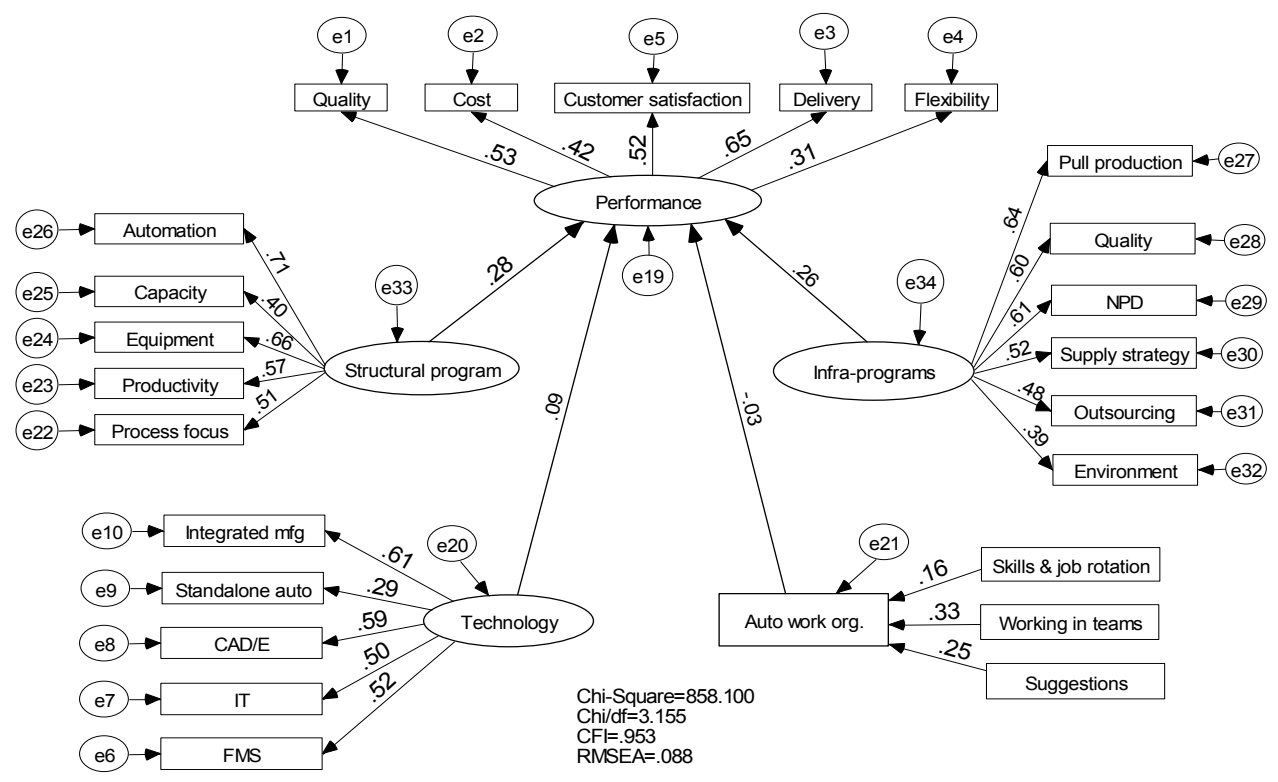

Fig. 2. The test of model-2 based on the multiple correlation principle

\subsection{Mode-3 \& 4 based on SEM}

Model-3 is specified based on the conceptual model (cf., figure 1) of manufacturing strategy and incorporates all the possible hypotheses among the five variables. It is the initial specified model for testing. The test result of model-3 is shown in the column of model-3 in table 5. The details are shown in figure 3 . The test shows that five paths are not significant. Obvious differences can be found between model-2 and model-3. In model-2, the paths for $\mathrm{H} 1$ and $\mathrm{H} 2$ are significant but not significant in model-3. According to the SEM principle, as long as there are non-significant paths, the whole model does not fit well and no conclusion can be drawn.

In the next step, the non-significant paths are removed one by one GRADUALLY and the model is tested again. The principle for removing non-significant paths should follow the principle from the least non-significant to the next least non-significant each by each. The reason is that removing one of the paths may change the path significance of other remaining paths. In this case, the path for $\mathrm{H} 2(\mathrm{p}=0.92)$ should be removed from the model first. Then the path for $\mathrm{H} 8(\mathrm{p}=0.89)$ is removed. The process continues until all the remaining paths are significant and the whole model fits well. Finally a model- 4 is obtained as shown in figure 4 . In this model, all the paths are significant and the whole model passes the fitness test as well. Therefore, conclusion can be drawn from model-4.

According to the results from model-4, it can be found that among the 10 hypotheses, four hypotheses are rejected and six are accepted, as shown the column of model- 4 in table 5 as well as figure 5. Hypotheses 1, 3, 4, 5, 7 and 10 are accepted, while hypotheses 2, 6, 8 and 9 are rejected. 


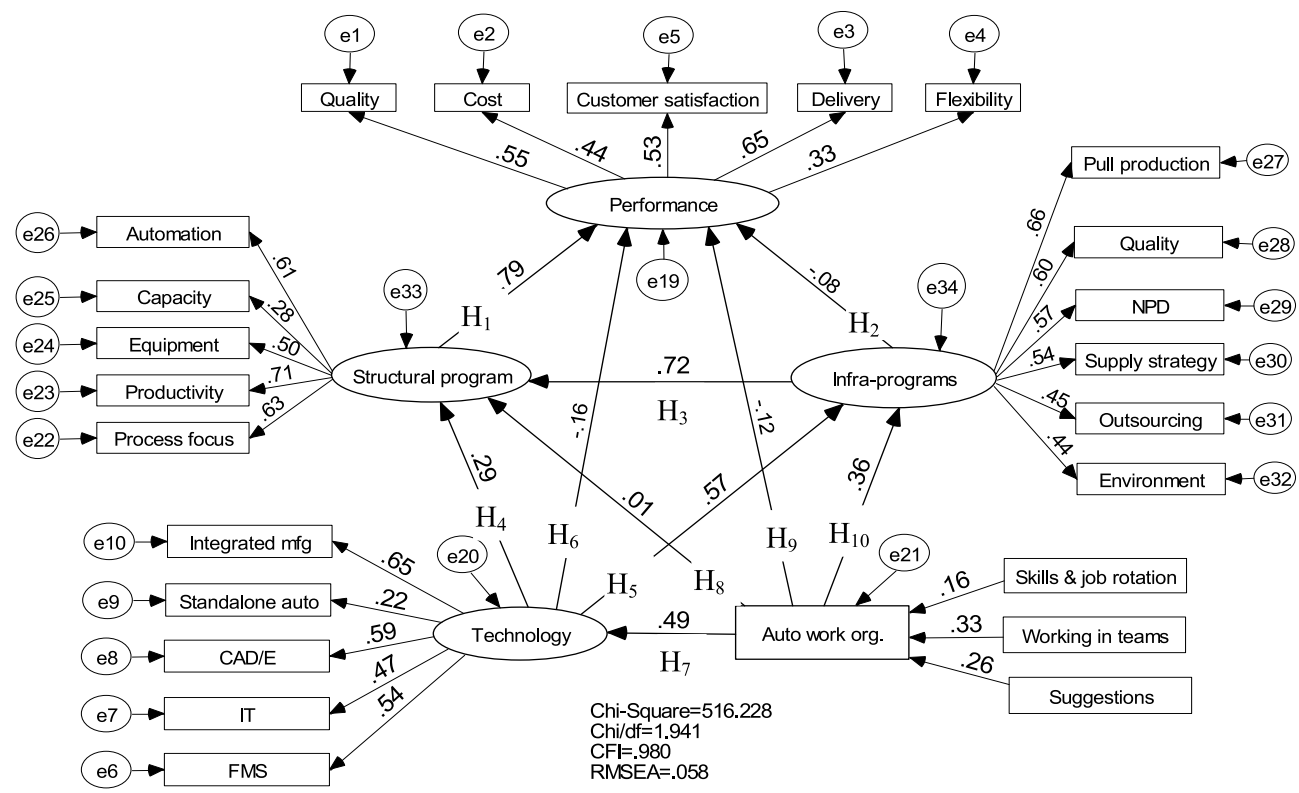

Fig. 3. The specified model (model-3) and test result

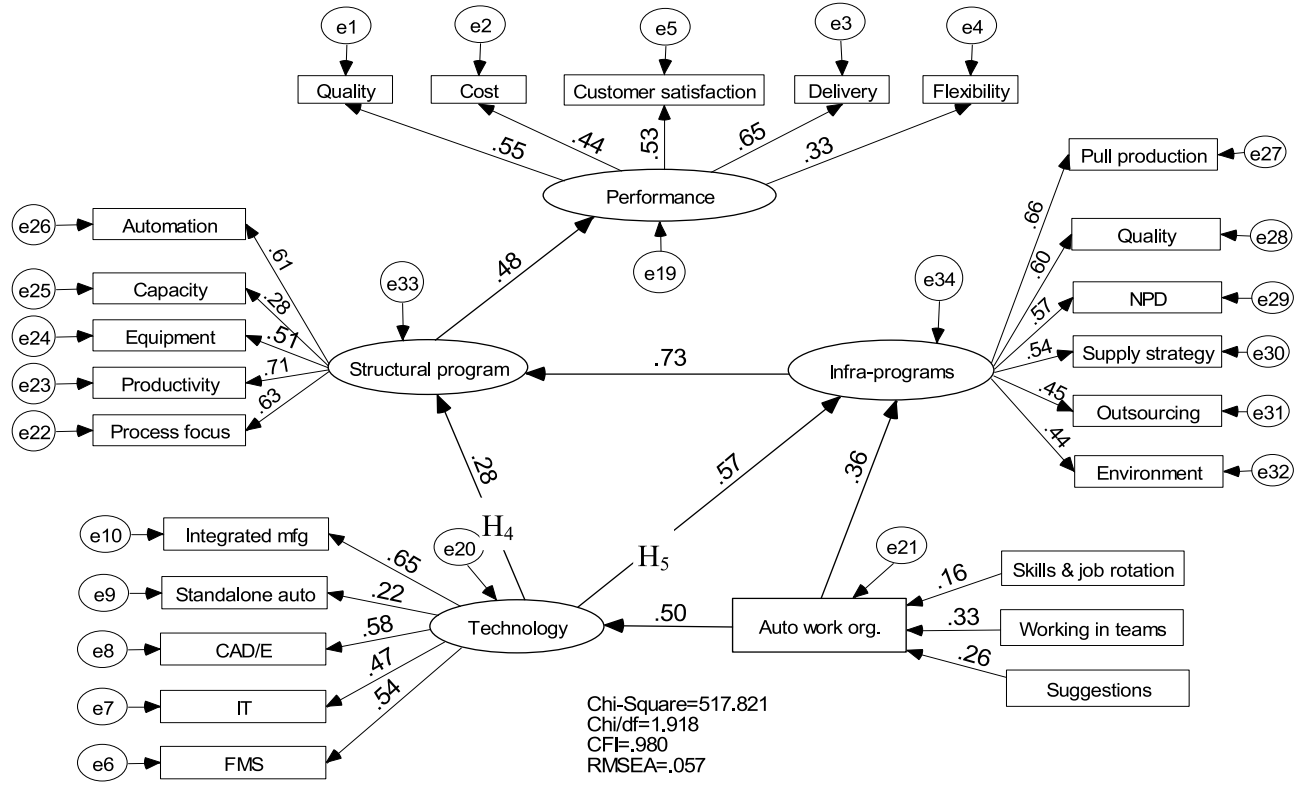

Fig. 4. The modified model (model-4) by gradually deleting no-significant paths 


\section{Discussions and implications}

The research finds that structural programs are the only practice that directly contributes to manufacturing performance, while other three dimensions such as infrastructural programs, technology and organization contribute indirectly through structural programs. The research results trigger the following discussions.

\subsection{Manufacturing process is the core}

This research reveals that the improvement programs that are related to the physical process directly contribute to manufacturing performance. The structural programs work on the manufacturing process. Therefore, the process is the core and direct factor that explains manufacturing performance. This can be supported by another stream of structural research on quality management. The research based on the USMBQA framework is also a structural model and produced very valid and reliable research results. For most of the research based this model, process management is directly correlated with performance (Kaynak, 2003, Meyer and Collier 2001, Pannirselvam and Ferguson 2001, Wilson and Collier 2000). The implication is very clear. To improve the manufacturing performance, it is critical to improve the manufacturing process.

\subsection{Infrastructure is the basis}

It is surprising that infrastructural programs like quality management, full production etc do not directly contribute to manufacturing performance. This is opposite to many previous studies on the relationship between quality management and performance. However, if looking at the research models in previous research, it will be possible to explain the difference. In previous research, only part of the programs is investigated and other relevant factors such as structural programs are ignored. When simple correlation or multiple correlation is used in this research, the infrastructural programs are found to be positively correlated with performance (cf., model-1 in table 5). Then the conclusion will be different.

The explanation is that infrastructural programs are useful. However, they do not contribute directly to performance but through the structural programs. The path loading between infrastructural to structural programs is very high $(0.73)$ and very significant $(p=0.001)$. These infrastructural programs are for the establishment of infrastructure. They support the manufacturing structural technical process. The finding implies that whatever infrastructural programs to be implemented, the evaluation may not be whether it directly contributes to performance, but the requirement of the process or programs related to the structural side of the process.

\subsection{Technology and organization are useful, but not directly contributing}

Technology is not found to be directly correlated with performance. In the past 20 years, AMT has been widely used by manufacturing companies all-over the world. However, world-wide research found that not all AMT perform as expected. Some AMTs performs "satisfactory", but did not produce the full benefits. Other AMTs perform well on the shop floor level, while the business performances of the companies were not improved (Voss, 1988). All these problems have caught the attention of both researchers and practitioners. 
Since the beginning of the 1980s, management of technology, especially implementation of AMT, has been a hot topic (Gerwin, 1982; Voss, 1988). The relationship between AMT and performance was investigated conceptually (Macbeth, 1989, p.71; Bishop and Schofield, 1989, p.44), by case studies (Sohal, 1996; Sun, Hjulstad and Frick, 1997) and by survey (Sun 2000, Small, 1998). Recent empirical research does not found that the use of AMT has direct impact on business or manufacturing performance (Swamidass and Kotha, 1998). The research by Beaumont et al (2002) intents to investigate AMT investment and performance in foreign-owned and Australian domestic companies. They did not conclude whether the AMT is significant related to performance. Sun (2000) found that little linear relationship exists between AMT and performance. The result from this research provides a reasonable explanation. Future research is needed to investigate the detail relationship between AMT and structural infrastructural action program. For example IT and supply chain management is one of the topic recently attracts researchers' attention.

\subsection{Methodological implications}

In this research, four different models are tested for the same set of hypotheses tests. Obvious differences are found among the four models. The differences have significant implications for selection of research methods on relationships among multiple variables. Simple correlation is simple and visual. However, its main limitation is the ignorance of the collinearity effects among variables. It can be used for identity or specify the preliminary model or explorative research at preliminary stage. Multiple correlation has the advantage of taking collinearity into consideration. However, it does not cover the interactions among the independent variables. If there are such interactions, multiple correlation results may not be reliable. Structural Equation Modeling (SEM) method is a good method since it covers collinearity effects and interactions among all the variables. As a result, it is more reliable for investigating relationships among multiple variables. More research on operations management, technology management and quality management are using more SEM to investigate multi-variant relationships (Kaynak, 2003, Meyer and Collier 2001, Pannirselvam and Ferguson 2001, Wilson and Collier 2000).

\section{Conclusions, limitations and future research}

The research in this paper has investigated the complex relationship among manufacturing practice and manufacturing performance. It is based on a structural model that incorporates all the possible linkages among practices and performance. The research may have the following contribution to the literature on practice-performance linkage. First, the research is based on the conceptual framework of manufacturing strategy, therefore, the model prevents from ignoring any possible linkages. Second, the data analysis is conducted with all available methods so that differences and limitations of simple and multiple correlation analysis are identified. Finally, the research produces several different results which are worthwhile to be considered in research in operations management.

The main message from this research is that not all practices may directly contribute to performance. It is the structural programmes that directly contribute to performance. Whatever other programs or technologies or organizational practices to be implemented, the final goal is to improve the manufacturing process. If the process is not improved, the contribution of other practices may not be realized. 
Since the research aims to be comprehensive and holistic, the scope of the paper is pretty wide. The ten hypotheses may not be fully discussed conceptually. The implications are not fully explored for each sub-relationship. Page and words limitation may also contribute to this weakness. However, in future research which looks at a sub-relationship, for example, between technology and structural programs, the conceptual part should be enhanced.

Some of the sub-relationships have been well studied. For example, the relationship between technology and HRS/organization has been studied insensitively in the past decades. However, future research may include the following topics, the relationship between technology and structural programmes, the relationship between technology and infrastructural programs, as well as the relationship between structural and infrastructural programs.

The research provides a conceptual model and data analysis approach for investigating practice-performance relationships. Triangulation research based on the model is welcomed and appreciated to cross-proof the validity of the research method. Based on this method, a series of comparative studies can be conducted, for example, between mass and job-shop process, between Small and Media Enterprises (SME) and larger companies, and between developed and developing countries.

\section{Appendix: Questions}

PT3. Please indicate to what extent your activity uses one of the following process types: (indicate percentage of total volume)

\begin{tabular}{ll}
$\begin{array}{l}\text { Process type } \\
\text { one of a kind } \\
\text { batches } \\
\text { mass production }\end{array}$ & $\frac{B P T 3 a}{B P T 3 b} \%$ \\
& $\underline{B P T 3 c} \%$ \\
\hline $\mathbf{1 0 0 \%}$
\end{tabular}

T1. Please indicate to what extent the operational activity is performed using the following technologies:

\begin{tabular}{|c|c|c|c|c|c|c|}
\hline & & \multicolumn{2}{|c|}{ No use } & & \multicolumn{2}{|c|}{ High use } \\
\hline Stand-alone/NC machines & BT11 & 1 & 2 & 3 & 4 & 5 \\
\hline Machining centres & BT12 & 1 & 2 & 3 & 4 & 5 \\
\hline CNC-DNC & BT13 & 1 & 2 & 3 & 4 & 5 \\
\hline $\begin{array}{l}\text { Automated tool change - parts } \\
\text { loading/unloading }\end{array}$ & BT14 & 1 & 2 & 3 & 4 & 5 \\
\hline Robots & BT15 & 1 & 2 & 3 & 4 & 5 \\
\hline Automated guided vehicles (AGVs) & BT16 & 1 & 2 & 3 & 4 & 5 \\
\hline Automated storage-retrieval systems (AS/RS) & BT17 & 1 & 2 & 3 & 4 & 5 \\
\hline $\begin{array}{l}\text { Flexible manufacturing/assembly systems - cells } \\
\text { (FMS/FAS/FMC) }\end{array}$ & BT18 & 1 & 2 & 3 & 4 & 5 \\
\hline Computer-aided inspection/ testing/ tracking & BT19 & 1 & 2 & 3 & 4 & 5 \\
\hline Computer aided design/engineering (CAD; CAE) & BT110 & 1 & 2 & 3 & 4 & 5 \\
\hline
\end{tabular}


Integrated design-processing systems (CAD-CAECAM-CAPP)

Engineering databases, Product Data

Management systems

LAN-WAN/ Intranet / Shared

databases/Internet

$\begin{array}{llllll}\text { BT111 } & 1 & 2 & 3 & 4 & 5 \\ \text { BT112 } & 1 & 2 & 3 & 4 & 5 \\ \text { BT113 } & 1 & 2 & 3 & 4 & 5\end{array}$

T2. To what extent are the following management areas software supported through the use of Enterprise Resource Planning systems?

Material management

Production planning and control

Purchasing and supply management

Sales and distribution management

Accounting and finance

Human Resources management

Project Management

Other (please specify

\begin{tabular}{clllll} 
& \multicolumn{2}{c}{ No use } & & \multicolumn{2}{c}{ High use } \\
\cline { 2 - 6 } BT21 & 1 & 2 & 3 & 4 & 5 \\
BT22 & 1 & 2 & 3 & 4 & 5 \\
BT23 & 1 & 2 & 3 & 4 & 5 \\
BT24 & 1 & 2 & 3 & 4 & 5 \\
BT25 & 1 & 2 & 3 & 4 & 5 \\
BT26 & 1 & 2 & 3 & 4 & 5 \\
BT27 & 1 & 2 & 3 & 4 & 5 \\
BT28b & 1 & 2 & 3 & 4 & 5
\end{tabular}

O1. At the end of the last fiscal year, in your business unit you had:

a. BO1a1 employees in total, of which BO1a2 were salaried employees,

b. $\quad$ BO1b $\%$ of salaried employees belonging to a union or similar workers associations.

c. BO1c \% of employees in total who are temporary (i.e. not permanent) workers

O2. How many organizational levels do you have (plant manager to first-line supervisors)? $\quad \mathbf{B O} 2$

O3. How many employees are under the responsibility of one of your line supervisors (on average)?

BO3a in Fabrication $\quad$ BO3b in Assembly

O4. a. What proportion of your direct employees are payed on incentives? employees

b. Among which (please select all relevant alternatives)

Work Group incentive $\square$ BO4b1, Individual incentive $\square \quad$ BO4b2, Companywide incentive $\quad \square$ BO4b3

O5. To what extent are your employees giving suggestions for product and process improvement?

No suggestions

12
3

\section{High number of suggestions}

4

5

O6. a. What proportion of your total work force work in teams? $\left(^{*}\right)$ :

in Fabrication BO6a \% in Assembly BO6b

O7. How many hours of training are given to new production workers? hours per new worker

O8. How many hours of training per year is regularly given to regular work-force? $\mathrm{BO} 8$ hours per employee 
O9. How many of your production workers do you consider as being $\underline{\text { multi-skilled? }}\left({ }^{*}\right)$ BO9 \% of total number of production workers.

$\left.{ }^{*}\right)$ Note: A multi-skilled operator is skilled in several operational tasks.

O10. How frequently do your production workers rotate between jobs or tasks?

\section{Never}

1
2
3

\section{Frequently}

5

C5 This question explores the action programs * to which your company is now devoting high resource and innovation effort and on which is concentrated the management focus and commitment. Please indicate whether the program has been undertaken within the last three years. (* By action program is meant a major project aimed at producing considerable changes in the company's management practices and organization )

\begin{tabular}{|c|c|c|}
\hline & Action programmes & $\begin{array}{l}\text { Degree of use } \\
\text { last } 3 \text { years }\end{array}$ \\
\hline C51a & Updating your process equipment to industry standard or better & 12345 \\
\hline C52a & $\begin{array}{l}\text { Expanding manufacturing capacity (e.g. buying new machines; } \\
\text { hiring new people; building new facilities; etc.) }\end{array}$ & 12345 \\
\hline$C 53 a$ & Engaging in process automation programs & 12345 \\
\hline C54a & $\begin{array}{l}\text { Implementing Information and Communication Technologies } \\
\text { and/or Enterprise Resource Planning software }\end{array}$ & 12345 \\
\hline C55a & $\begin{array}{l}\text { Reorganizing your company towards e-commerce and/or e- } \\
\text { business configurations }\end{array}$ & 12345 \\
\hline$C 56 a$ & $\begin{array}{l}\text { Rethinking and restructuring your supply strategy and the } \\
\text { organization and management of your suppliers portfolio }\end{array}$ & 12345 \\
\hline$C 57 a$ & $\begin{array}{l}\text { Concentrating on your core activities and outsourcing support } \\
\text { processes and activities (e.g. IS management, maintenance, } \\
\text { material handling, etc.) }\end{array}$ & 12345 \\
\hline C58a & $\begin{array}{l}\text { Restructuring your manufacturing processes and layout to obtain } \\
\text { process focus and streamlining (e.g. reorganize plant-within -a- } \\
\text { plant; cellular layout, etc.) }\end{array}$ & 12345 \\
\hline C59a & $\begin{array}{l}\text { Undertaking actions to implement pull production (e.g. reducing } \\
\text { batches, setup time, using kanban systems, etc.), }\end{array}$ & 12345 \\
\hline C510a & $\begin{array}{l}\text { Undertaking programs for quality improvement and control (e.g. } \\
\text { TQM programs, } 6 \sigma \text { projects, quality circles, etc.) }\end{array}$ & 12345 \\
\hline C511a & $\begin{array}{l}\text { Undertaking programs for the improvement of your equipment } \\
\text { productivity (e.g. Total Productive Maintenance programs) } \\
\text { Implementing actions to increase the level of delegation and }\end{array}$ & 12345 \\
\hline C512a & $\begin{array}{l}\text { knowledge of your workforce (e.g. empowerment, training, } \\
\text { improvement or autonomous teams, etc.) }\end{array}$ & 12345 \\
\hline C513a & $\begin{array}{l}\text { Implementing actions to improve or speed-up you process of new } \\
\text { product development through e.g. platform design, products } \\
\text { modularization, components standardization, concurrent } \\
\text { engineering, Quality Function Deployment, etc. }\end{array}$ & 12345 \\
\hline
\end{tabular}


Putting efforts and commitment on the improvement of your

C514a company's environmental compatibility and workplace safety and healthy

D2. Please indicate the amount of change of the following performance dimensions over the last three years

\begin{tabular}{llccccc}
\hline & & $\begin{array}{c}\text { Strongly } \\
\text { deteriorated }\end{array}$ & $\begin{array}{c}\text { No } \\
\text { change }\end{array}$ & $\begin{array}{c}\text { Strongly } \\
\text { improved }\end{array}$ \\
\hline Manufacturing conformance & $\mathbf{D 2 1}$ & 1 & 2 & 3 & 4 & 5 \\
Product quality and reliability & $\mathbf{D 2 2}$ & 1 & 2 & 3 & 4 & 5 \\
Product customization ability & $\mathbf{D 2 3}$ & 1 & 2 & 3 & 4 & 5 \\
Volume flexibility & $\mathbf{D 2 4}$ & 1 & 2 & 3 & 4 & 5 \\
Mix flexibility & $\mathbf{D 2 5}$ & 1 & 2 & 3 & 4 & 5 \\
Time to market & $\mathbf{D 2 6}$ & 1 & 2 & 3 & 4 & 5 \\
Customer satisfaction & $\mathbf{D 2 7}$ & 1 & 2 & 3 & 4 & 5 \\
Delivery speed & $\mathbf{D 2 8}$ & 1 & 2 & 3 & 4 & 5 \\
Delivery reliability & $\mathbf{D 2 9}$ & 1 & 2 & 3 & 4 & 5 \\
Manufacturing lead time & $\mathbf{D 2 1 0}$ & 1 & 2 & 3 & 4 & 5 \\
Procurement lead time & $\mathbf{D 2 1 1}$ & 1 & 2 & 3 & 4 & 5 \\
Procurement costs & $\mathbf{D 2 1 2}$ & 1 & 2 & 3 & 4 & 5 \\
Labor productivity & $\mathbf{D 2 1 3}$ & 1 & 2 & 3 & 4 & 5 \\
Inventory turnover & $\mathbf{D 2 1 4}$ & 1 & 2 & 3 & 4 & 5 \\
Capacity utilization & $\mathbf{D 2 1 5}$ & 1 & 2 & 3 & 4 & 5 \\
Overhead costs & $\mathbf{D 2 1 6}$ & 1 & 2 & 3 & 4 & 5 \\
Environmental performance & $\mathbf{D 2 1 7}$ & 1 & 2 & 3 & 4 & 5
\end{tabular}

\section{References}

Ayres, Robert (1991) Computer Integrated Manufacturing Volume I: Revolution in Progress, CHAPMAN \& HALL, London.

Beaumont, N., Schroder, R. and Sohal, A. (2002) Do foreign-owned firms manage advanced manufacturing technology better? International Journal of Operations \& Production Management; Vol. 22, No. 7/8, pg. 759-772.

Beekun, R. I. (1990) "Assessing the effectiveness of socio-technical interventions: Anitdore or fad?", Human Relations, Vol. 42, pp.887-897.

Beekun, R. I. (1990) "Assessing the effectiveness of socio-technical interventions: Anitdore or fad?", Human Relations, Vol. 42, pp.887-897.

Bessant, J. and Haywood, B., (1988), "Islands, archipelagos and continents: progress on the road to computer-integrated manufacturing", Research Policy, Vol. 17, 349-362.

Byrne, B.M., 2001. Structural Equation modeling with AMOS: Basic Concepts, Applications and Programming. Lawrence Erlbaum Associates, Publishers, NJ.

Chase, R. B. and Aquilano, N. (1997) Production and Operations Management, IRWIN, Chicago.

Chase, R. B., Aquilano, N. and Jacobs, R. (2001) Operations management for competitive advantage (9th ed.) Boston : McGraw-Hill/Irwin 
Cohen, J. (1988), Statistical power analysis for the behavioral sciences, 2nd ed. Hillsdale, N.J. : L. Erlbaum Associates, 1988.

Cua, K. O. McKone, K. E. and Schroeder, R. G. (2001) Relationships between implementation of TQM, JIT, and TPM and manufacturing performance. Journal of Operations Management. Vol.19, No. 6, pp. 675-694.

Dasa, A. and R., Narasimhan (2001) Process-technology fit and its implications for manufacturing performance, Journal of Operations Management 19 (2001) 521-540

de Vaus, D. A., (1993), Survey in Social Research (3rd ed.), UCL PRESS.

Fix-sterz, Jutta, Gunter Lay, Rainer S., Jurgen W. (1987), Flexible Manufacturing Systems and Cells in the Scope of New Production Systems in Germany, FAST Occasional paper No.135.

Flynn, B. B., Schroeder, R. G., and Sakakibala, S. (1994), "A framework for quality management research and an associated measurement instrument", Journal of Operations Management, Vol. 11, pp.1339-1366.

Gerwin, D. and H. Kolodny (1992) Management of advanced manufacturing technology: strategy, organisation, and innovation, Wiley \& Sons, N.Y.

Goetsch, D. L., (1990) Advanced Manufacturing Technology, Delmar Publisher Inc., New York

Greenwood, N. R. (1988) Implementing Flexible Manufacturing System, Macmillan Education, London.

Groover, M. P. (1987), Automation, Production Systems, and Computer Integrated Manufacturing, Prentice-Hall, Inc., New Jersey.

Hanson, P. and Voss, C.A., (1993), Made in Britain, the true state of Britain's manufacturing industry, IBM Ltd/London Business School, Warwick, UK.

Hayes, R. H., Wheelwright, S. C. and Clark, K. B., (1988), Dynamic manufacturing, creating the learning organization. The Free Press, New York, NY.

Hayes, R.H. and Wheelwright, S.C. (1984) Restoring Our Competitive Edge. Wiley, New York.

Hayes, R.H. and Wheelwright, S.C., (1984), Restoring our competitive edge, Wiley, New York.

Haywood, B. (1990) "CIM: technologies, organisations, and people in transition", Proceedings of the final IIASA conference on CIM, Luxembourg, Austria.

Hill, T., (1995), Manufacturing strategy: Text and cases, Macmillan Press, London.

$\mathrm{Hu}$, L., Bentler, P.M., 1998. Fit indices in covariance structure modeling: Sensitivity to underparameterized model misspecification. Psychological Methods 3, 424-453.

$\mathrm{Hu}$, L., Bentler, P.M., 1999. Cutoff criteria for fit indexes in covariance structure analysis: conventional criteria versus new alternatives. Structural Equation Modeling 6(1), 1-55.

Jöreskog, K.G. and Sörbom, D., 1984. LISREL-VI user's guide (3rd ed.). Scientific Software, Mooresville, IN.

Kaynak, H. 2003. The relationship between total quality management practices and their effects on firm performance. Journal of Operations Management 21, 405-435.

Kim J.S., Arnold, P., 1996. Operationalizaing manufacturing strategy: an exploratory study of constructs and linkage. International Journal of Operations \& Production Management 16(12), 45-73.

Kopelman, R. E. (1986) Managing Productivity in Organizations, McGraw, NY.

Kotha, S and P M Swamidass (2000) Strategy, advanced manufacturing technology and performance: Empirical evidence from U.S. manufacturing firms, Journal of Operations Management. Vol. 18, No. 3: 257

Kotha, S. and P. M., Swamidass, (1998), "Advanced Manufacturing Technology uses: exploring the effect of the nationality variable", International Journal of Production Research, Vol. 11, pp.3135-3146. 
Lee, R. J. V. and Leonard, R. (1990), "Changing role of humans within an integrated automated guided vehicle system", Computer-Integrated manufacturing Systems, Vol. 3. No.2, pp.115-120.

Leong, G.K. and Ward, P.T., (1995), The six Ps of manufacturing strategy, International Journal of Operations \& Production Management, Vol. 15, No. 12, p 32-45.

Lewis, M.A. and Roehrich, J. (2009), "Contracts, relationships and integration: towards a model of the procurement of complex performance", International Journal of Procurement Management, Vol. 2 No. 2, pp. 125-142.

Lindberg, P. (1990) Manufacturing Strategy and Implementation of Advanced Manufacturing technology, Ph.D. Dissertation, Chalmers University of Technology, Gothenburg, Sweden.

Lindberg, P., Voss, C.A., Blackmon, K.L. (Eds), 1998. International Manufacturing Strategies: Context, Content and Change. Kluwer Academic Publisher, Boston.

MacCallum, R., 1986. Specification searches in covariance structure modeling. Psychological Bulletin 100(1), 107-120.

MacCallum, R.C., James, T. A., 2000. Applications of structural equation modeling in psychological research. Annual Review of Psychology 51, 201.

Marsh, H.W. and Hocevar, D., 1985. Application of confirmatory factor analysis to the study of self-concept: first- and higher-order factor models and their invariance across groups. Psychological Bulletin 97, 562-582.

McDermott, C.M., Stock, G.N. (1999) Organizational culture and advanced manufacturing technology implementation. Journal of Operations Management 17 (5), 521-533.

McDermott, C.M., Stock, G.N., 1999. Organizational culture and advanced manufacturing technology implementation. Journal of Operations Management 17 (5), 521-533.

Meyer, S. M. and A. Collier. 2001. An empirical test of the causal relationships in the Baldrige Health Care Pilot Criteria. Journal of Operations Management 19(4), 403:425.

Ng, K.C. and Hung, I. W., (2001), A model for global manufacturing excellence, Work Study, Vol. 50, No. 2, p 63-68.

Noori, H. (1990) Managing the Dynamics of New Technology, issues in manufacturing management, Prentice Hall, Englewood Cliffs, N.J.

Nunnally, J. C. (1978), Psychometric Theory, McGraw-Hill Publishing Company, New Yor.

Nunnally, J.C., Bernstein I.H., 1994. Psychometric theory. McGraw-Hill, New York, 510-512.

Pannirselvam, G.P., Ferguson, L.A., 2001. A study of the relationships between the Baldrige categories. International Journal of Quality and Reliability Management 18 (1), 14-34.

Parthasarthy, R. and S. P. Sethi (1992) "The Impact of flexible automation on business strategy and organizational structure", Academy of Management Review, Vol. 17, No:1. pp.86-112.

Peterson, R.A., 1994. A meta-analysis of Cronbach's coefficient alpha. Journal of Consumer Research 21(2), 381-391.

Riis, O.J. ( 1992) "Integration and Manufacturing Strategy". Computer in Industry, vol. 19, 37-50.

Samson, D., Sohal, A. and Ramsay, E., (1993) "Human resources issues in manufacturing improvement initiatives: case study experiences in Australia", The International Journal of Human Factors in Manufacturing, Vol.3, No. 2, pp.153-152. 
Saraph, J. V., and Sebastian, R. J. (1992), "Human resources strategies for effective introduction of advanced manufacturing technologies (AMT)", Production and Inventory Management Journal, Vol.33, pp.764-770.

Saraph, J. V., Benson, P. G., and Schoeder, R. G. (1989), "An instrument for measuring the critical factors of quality management", Decision Sciences, Vol. 20, pp.810-829.

Schonberger, R. J., (1982), Japanese Manufacturing Techniques, Nine Hidden Lessons in Simplicity, The Free Press, New York NY.

Schonberger, R.J., (1986), World Class Manufacturing: The Lessons of Simplicity Applied, The Free Press, New York, NY.

Schroeder, R.G., Anderson, J.C., and Cleveland, G., (1986), The content of manufacturing strategy: An empirical study, Journal of Operations Management, Vol. 6, No. 4, p 405-415

Singh, N. (1996) System Approaches to Computer Integrated Design and Manufacturing, John Wiley \& Sons, Inc., N.Y.

Skinner, W., 1969. Manufacturing-missing link in corporate strategy, Harvard Business Review 47(3), 136-145.

Sobek II, D. K., Liker, J. K. and Ward, A. C. 1998, Another look at how Toyota integrate product development, Harvard Business Review, July-August issue, pp.69-78.

Sun, H. (2000) "Current and Future Patterns of Using Advanced Manufacturing Technologies", Technovation, The International Journal of Technological Innovation and Entrepreneurship, Vol.20, No.11, pp.631-641.

Sun, H. (2001) "Human Resources Development in Integrated Manufacturing Systems", Integrated Manufacturing System, Vol. 12, No.3, pp.195-204

Sun, H. and Cui, H. (2002) The alignment between manufacturing and business strategies: its influence on business performance. Technovation 22, 699-705.

Sundstrom, E., DeMeuse, K.P., and Futell, D. (1990), "Work teams", American Psychologist, Vol. 45, pp. 120-133.

Swamidass, P.M. and Newell, W.T. (1987) "Manufacturing strategy, environmental uncertainty and performance": a path analytic model. Management Science, vol.33, 509-524.

Swamidass, P.M., Kotha, S. (1998) Explaining manufacturing technology use, firm size and performance using a multidimensional view of technology. Journal of Operations Management 17 (1), 23-37.

Tseng, H.C., Ip, W.H., and Ng, K.C., (1999), A model for an integrated manufacturing system implementation in China: a case study, Journal of Engineering and Technology Management, 16, p83-101.

Tunalv, C. (1991) Manufacturing strategy in Sweden engineering industry", Ph.D. thesis, Chalmes University of Technology, Sweden.

Wheaton, B., Muthen, B., Alwin, D.F. and Summers, G.F., 1977. Assessing reliability and stability in panel model. In: Heise, D.R. (Ed), Sociological Methodology. JosseyBsaa, San Francisco, 84-136.

Wheelwright, S. C., (1984), Manufacturing strategy: Defining the missing link, Strategic management Journal, 1, p 77-91.

Wilson, D.D., Collier, D.A., 2000. An empirical investigation of the Malcolm Baldrige National Quality Award causal model. Decision Sciences 31 (2), 361-390.

Woodward, Joan (1965) Industrial Organization: Theory and practice. London: Oxford University press. 


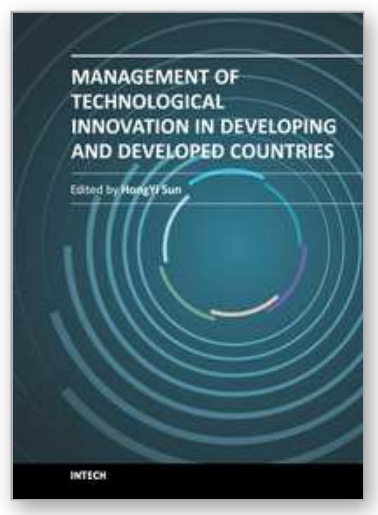

\section{Management of Technological Innovation in Developing and Developed Countries}

Edited by Dr. HongYi Sun

ISBN 978-953-51-0365-3

Hard cover, 312 pages

Publisher InTech

Published online 21, March, 2012

Published in print edition March, 2012

It is widely accepted that technology is one of the forces driving economic growth. Although more and more new technologies have emerged, various evidence shows that their performances were not as high as expected. In both academia and practice, there are still many questions about what technologies to adopt and how to manage these technologies. The 15 articles in this book aim to look into these questions. There are quite many features in this book. Firstly, the articles are from both developed countries and developing countries in Asia, Africa and South and Middle America. Secondly, the articles cover a wide range of industries including telecommunication, sanitation, healthcare, entertainment, education, manufacturing, and financial. Thirdly, the analytical approaches are multi-disciplinary, ranging from mathematical, economic, analytical, empirical and strategic. Finally, the articles study both public and private organizations, including the service industry, manufacturing industry, and governmental organizations. Given its wide coverage and multidisciplines, the book may be useful for both academic research and practical management.

\section{How to reference}

In order to correctly reference this scholarly work, feel free to copy and paste the following:

Hongyi Sun (2012). Linking Process Technology and Manufacturing Performance Under the Framework of Manufacturing Strategy, Management of Technological Innovation in Developing and Developed Countries, Dr. HongYi Sun (Ed.), ISBN: 978-953-51-0365-3, InTech, Available from:

http://www.intechopen.com/books/management-of-technological-innovation-in-developing-and-developedcountries/linking-process-technology-and-manufacturing-performance-under-the-framework-of-manufacturingstrate

\section{INTECH}

open science | open minds

\section{InTech Europe}

University Campus STeP Ri

Slavka Krautzeka 83/A

51000 Rijeka, Croatia

Phone: +385 (51) 770447

Fax: +385 (51) 686166

www.intechopen.com

\section{InTech China}

Unit 405, Office Block, Hotel Equatorial Shanghai

No.65, Yan An Road (West), Shanghai, 200040, China

中国上海市延安西路65号上海国际贵都大饭店办公楼 405 单元

Phone: +86-21-62489820

Fax: +86-21-62489821 
(C) 2012 The Author(s). Licensee IntechOpen. This is an open access article distributed under the terms of the Creative Commons Attribution 3.0 License, which permits unrestricted use, distribution, and reproduction in any medium, provided the original work is properly cited. 